\title{
Understanding CEO Role Perception and Time Usage: Are New Municipal Typologies Useful?
}

\author{
Robert D. Eskridge ${ }^{1}$ \\ ${ }^{1}$ Department of Government and Justice Studies, Appalachian State University, Boone, NC, USA \\ Correspondence: Robert D. Eskridge, Anne Belk Hall, ASU Box 32107, Department of Government \& Justice \\ Studies, Appalachian State University, Boone, NC., 28708-2107, USA. Tel: 1-828-262-4074. E-mail: \\ eskridgerd@appstate.edu
}

Received: January 31, 2014 Accepted: February 12, 2014 Online Published: April 29, 2014

doi:10.5539/par.v3n1p52 URL: http://dx.doi.org/10.5539/par.v3n1p52

\begin{abstract}
In recent years local government scholars have sought to more explicitly describe the diverse structures that exist within municipalities by developing typologies that extend beyond the traditional mayor-council versus council-manager form definitions. This research explores the value of these new typologies in helping scholars explain differences among chief executive officers (mayors and city managers) in municipalities. Using information obtained from a national random survey of municipalities, this study evaluates two of the most developed new typologies along with the traditional mayor-council versus council-manager classification in terms of how officials allocate their work time and how municipal mayors and city managers perceive both their own and their city councils role in the council/executive relationship. Using the percentage of work time allocated to the "Policy", "Politics", and "Management" activities as describe by Ammons and Newell in their 1987 Public Administration Review study (Role Emphases of City Managers and Other Municipal Executives) and the role perceptions of mayors and city managers using the four role dimensions of "Mission", "Policy", "Administration", and "Management" described in the Dichotomy/Duality model developed by James Svara in his 1985 Public Administration Review article "Dichotomy and Duality: Reconceptualizing the Relationship Between Policy and Administration in Council-Manager Cities", the differences between and among chief executive officers (CEO) are exaimined. We find that differences do exist between mayor and city manager CEOs and that by using new typologies, differences within mayors in mayor-council cities exist but do not exist among city managers in council-manager cities.
\end{abstract}

Keywords: executive behavior, council relations, municipal typologies

\section{Introduction}

One of the unique features of municipal government in the United States is the variety of institutional structures that can be found from one location to the next. Although the International City / County Management Association (ICMA) recognizes the five most common forms of local government (including the mayor-council, council-manager, commission, town-meeting, and representative-town-meeting forms), most research on local government structure in the U.S. focuses on the two structural forms that dominate the American municipal landscape, namely the mayor-council (34\% of municipalities) and council-manager (55\% of municipalities) forms (DeSantis \& Renner, 2002; MacManus \& Bullock 2003; Moulder, 2008). Scholars often use this dichotomous classification system to analyze the effects of form of government on a number of variables including characteristic differences between mayors and city managers (Nolting, 1969; Stillman, 1974; Wikstrom, 1990; DeSantis and Newell, 1996); time allocation (Wright, 1969; Ammons \& Newell, 1989; Newell \& Ammons, 1987); and the influence of demographic and socio-demographic variables on form of government (Sherbenou, 1961; Kessel, 1962; Dye \& MacManus, 1976; Sanders, 1979; Giles, Gabris, \& Krane, 1980; Farnham, 1986).

Recent research has suggested that this traditional mayor-council (unreformed government) or council-manager (reformed government) classification scheme does not fully capture the variations in government form that have evolved over the past decades (DeSantis \& Renner, 2002). Changes including an increased use of appointed chief administrative officers (CAOs) in mayor-council form cities, the direct election of mayors and an increased use of ward or district elections for city council members in council-manager municipalities have all been observed in recent years (Adrian, 1988; Moulder, 2008; MacManus \& Bullock, 2003; Ebdon \& Brucato, 2000; Frederickson, 
Logan, \& Wood, 2003). Scholars have proposed new ways of classifying municipalities based on different institutional characteristics found in municipalities. Bill Hansell (1998a; 1998b) suggested that council-manager cities be classified into four categories based upon the characteristics found within the mayoral position (Note 1). DeSantis and Renner (2002) expanded on Hansell's typology by adding mayor-council form cities with a weak or strong mayor and with or without an appointed chief administrative officer (cao).

Nelson and Svara (2010) attempted to improve upon this system using a seven category system based primarily upon the allocation of authority, how executive responsibilities are assigned, and administrative accountability (to the mayor or the council). Also, Frederickson, Johnson, and Wood (2004b) developed a new municipal classification system that focuses upon a number of existing structural variables. To better describe the similarities and differences present in municipalities today, their framework splits the two traditional forms of local government into five separate categories including: "Political Cities", "Administrative Cities", "Adapted Political Cities", "Adapted Administrative Cities", and "Conciliated Cities".

The debate over how changes in the institutional dynamics of modern municipalities can best be captured using new enhanced typologies is ongoing, and additional research is essential in determining their relativity and utility. This study utilizes two of the most comprehensive new taxonomies (along with the traditional mayor-council and council-manager typology) to examine whether this classification can offer insight concerning how the chief executive officer (CEO) of local municipalities (mayors in mayor-council form cities and city managers in council-manager form cities) allocate their work time and perceive of their role (Figure 1 below compares the three typologies and where they fit along a hypothetical reformed - unreformed dimension).

\begin{tabular}{|c|c|c|c|}
\hline & Traditional Form & Adapted Cities Typology & Nelson-Svara Typology \\
\hline \multirow{2}{*}{ Unreformed Cities } & \multirow{2}{*}{ Mayor-Council } & $\begin{array}{l}\text { Political } \\
\text { Adapted Political }\end{array}$ & $\begin{array}{l}\text { Mayor-Council } \\
\text { Mayor-Administrator-Council }\end{array}$ \\
\hline & & Conciliated & $\begin{array}{l}\text { Mayor-Council-Administrator } \\
\text { Mayor and Council-Administrator }\end{array}$ \\
\hline $\begin{array}{c}\downarrow \\
\text { Reformed Cities }\end{array}$ & Council-Manager & $\begin{array}{l}\text { Adapted Administrative } \\
\text { Administrative }\end{array}$ & $\begin{array}{l}\text { Empowered } \\
\text { Mayor-Council-Administrator } \\
\text { Mayor-Council-Manager } \\
\text { Council (Mayor) Manager }\end{array}$ \\
\hline
\end{tabular}

Figure 1. Comparison of the three typologies

This paper first examines, using these three typologies, how mayors and managers actually use their work time by examining time allocation between the "Political", "Policy", and "Management" work roles as described by Newell and Ammons (1987) in their 1987 Public Administration Review article and subsequent book (Ammons \& Newell, 1988). It is anticipated that that if the institutional changes described in each typology make a difference in the duties that a mayor or manager conceive of as part of their role, the analysis should then reveal differences in how these officials allocate their work time. How each mayor and manager rates their own and their city council's involvement levels within the "Mission", "Policy", "Administrative", and "Management" activities as described by Svara's (1985) Dichotomy/Duality model is examined next. Again, it is hoped that analysis reveals any differences in involvement levels that might be correlated with the institutional changes described by the new typologies.

\section{Form of Government and Time Allocation}

Over the past fifty years research examining how city officials allocate their work time has been an area of interest for many scholars. Much of this interest stems from the complexity of roles scholars discover in the position of the city manager in local governments, and numerous studies have demonstrated that city managers are required to participate in many areas outside their administrative realm (Ammons \& Newell, 1988; Blubaugh, 1987; Bosworth, 1958; Loveridge, 1968). Deil S. Wright (1969) posits that the behavior of city managers is characterized by the use 
of three analytically distinct role categories; namely, the roles that city managers take in the realms of managerial, policy, and political activities. He found that $60 \%$ of a manager's time was devoted to management activities, $21 \%$ was devoted to policy making activities and $16 \%$ was spent on political activities. Subsequent research on form of government and its relation to the allocation of working time by the chief administrative officer of a municipality shows that these CEOs do allocate the time that they spend on the job between various activities associated with these different roles. The three roles originally put forward by Wright (1969), namely the roles of "Management", "Policy", and "Political", still seem to explain the primary activities that contemporary chief executive officers perform; although the roles of chief executive officers have been looked at using different perspectives (Aleshire \& Aleshire, 1977; Blubaugh, 1987; and Hale, 1989). These studies find that most administrators spend a great deal of their time on those activities that are related to the "Management" role, less on "Policy" role activities, and the smallest proportion on "Political" role activities (Newell \& Ammons, 1987; Newell, Glass, \& Ammons, 1995; French \& Folz, 2004; Killian \& Choudhury, 2010).

In this study the author intends to enhance the existing literature concerning the time allocations by mayors and city managers by using the newer form of government typologies and observing differences in how executives allocate their work time between the "Administrative", "Policy", and "Political" role activities. Previous studies have primarily focused on the differences between CEOs using the traditional mayor-council and council-manager forms of government. For this study, the intent is to expand the current literature on executive time allocation by examining time allocations using these new more complex typologies for classifying municipalities. Based upon the above discussion hypothesis 1 is proposed.

Hypothesis 1: Mayors in mayor-council form cities allocate a larger percentage of their work time to political and policy activities and less to management activities that city managers serving in council-manager cities.

\section{Division of Responsibilities and Form of Government}

The existence of the politics-administration dichotomy is one of the enduring theoretical constructs in public administration (Svara, 1999b) and continues to persist even though many eminent scholars have examined the history of the traditional dichotomy model and brought into question the validity of its presence even at the beginning of the field (Rosenbloom, 2008; Lynn, 2001; Svara, 1999a, Waldo, 1948). In the context of local government this theoretical model holds that; 1 ) "the city council does not get involved in administration", and 2) "the city manager has no involvement in shaping policies" (Svara, 1999b, p. 51). However, numerous studies of municipalities conducted by local government scholars over the years have found this theoretical separation of administration implementation and policy shaping wanting (Loveridge, 1968; Ammons \& Newell, 1988; Dunn \& Legge, 2002; Golembiewski \& Gabris, 1994; Montjoy \& Watson, 1995).

The Dichotomy / Duality Model proposed by Svara (1985) divides the old politics-administration dichotomy into four separate dimensions, "Mission", "Policy", "Administration", and "Management" (See Figure 2). These four functions of the governmental process "blend" into each other in a continuum and yet are conceptually distinctive from each other and can thus be operationalized for analysis (Svara, 1985). The "Mission" and the "Management" functions, at the two extremes of the continuum, are largely dichotomized, with elected officials primarily responsible for the "Mission" functions and administrators for "Management" functions. The two internal activities on the continuum, namely the "Policy" and "Administration" functions, consist of shared responsibilities (duality) between elected and appointed officials. Svara's model graphically displays this distribution of responsibility between the elected council and the appointed manager for these four distinct functions, using a line to show the division of responsibility.

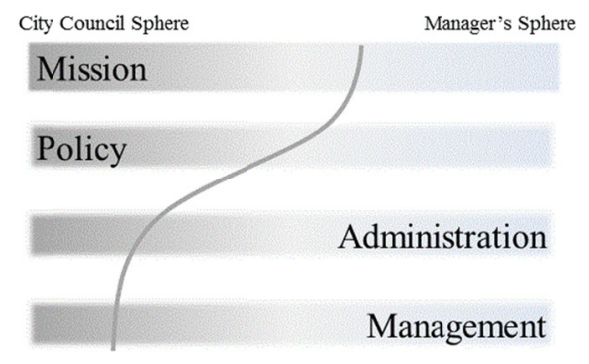

Figure 2. Svara's dichotomy-duality model 
Svara (1985) also suggests that this model can also be applied to the examination of municipal mayors in mayor-council municipalities as well as city managers in council-manager cities. He suggests that if the model is applied to mayors these mayors would play a larger role in the "Mission" and "Policy" roles and "the responsibility for legislators would be sustainably smaller than in the council-manager form" (Svara, 1985, p.232).

Svara's model allows for neither a complete separation of policy and administration nor a complete intermingling. It protects the conditions for democratic governance but also allows for the best use of the talents of both administrators and elected officials (Svara, 1985). Subsequent research substantiates the utility of the Dichotomy-Duality model (Browne, 1985; Protasel, 1995; Svara, 1988a, 1988b, 1995, 1999, 2006; Demir, 2009). Later research by Svara suggests that the original Dichotomy / Duality model may be an oversimplification of the relationship between officials and their elected councils and he advocates the use of a new "Complementarity" model (Svara 1999, 2006). For this study, we retain the use of the original model for its analytical ability to distinguish between the four distinct sets of activities. Based upon the above discussion we propose hypotheses 2 and 3 .

Hypothesis 2: Mayors in mayor-council form cities will be more involved in the "Mission" and "Policy" role activities than city managers serving in council-manager cities.

Hypothesis 3: City councils in mayor-council cities will exhibit lower involvement levels in the "Mission", "Policy", "Administration", and "Management" dimensions than city councils in council-manager form cities.

\section{Adapted Cities Framework}

One of the most comprehensive empirical attempts to reexamine and improve upon the analytic ability found in using the traditional mayor-council / council-manager typology for analysis can be found in the "Adapted Cities" framework. H. George Frederickson, along with Gary Johnson and Curtis Wood, through a number of articles published during the early 2000's (Frederickson \& Johnson, 2001; Frederickson, Wood, \& Logan, 2001; Frederickson, Logan, \& Wood, 2003; Frederickson, Johnson, \& Wood, 2004b) and cumulating in the book The Adapted City: Institutional Dynamics and Structural Change (Frederickson, Johnson, \& Wood, 2004a), have undertaken a thorough review of the vast diversity of institutional structures that exists in cities within the United States. They develop a new municipal classification system that focuses upon a number of existing structural variables. These three scholars utilize this new classification system to illustrate how over time most cities within the U.S. (especially those over 50,000 in population) have incrementally changed their institutional structure so that today most municipalities no longer fit clearly into either the traditional mayor-council (their "Political cities") or the council-manager (their "Administrative cities") distinctions. It is Frederickson, Johnson, and Wood's assertion that most municipalities are now better classified using one of their two adapted cities types (Frederickson et al., 2004a).

The "adapted cities" categories can be described as follows: 1) Political Cities: these cities represent the classical political extreme; they utilize a separation of powers structure between the council and the mayor with the mayor acting as CEO and not serving on the city council; 2) Adapted Political Cities: these cities are most clearly distinguished from pure political cities by the presence of a professional chief administrative officer (CAO) appointed by the mayor; 3) Conciliated Cities: these cities are no longer obviously based solely on a separation of powers model or a unity of powers model. They have a CAO that is appointed jointly by the mayor and council and the council may be elected at-large or by district in the city; 4) Adapted Administrative Cities: these cities are usually distinguished from pure administrative cities in that the mayor is directly elected, may have the veto, may be full-time, and may have additional input into the manager's appointment. 5) Administrative Cities: these cities represent the classical council-manager unity-of-power form with the mayor appointed from among the council, serving as a member of council with no separate executive duties, the council is part-time, elected at-large with usually shorter terms ( 2 year terms), the manager is appointed by the entire council and is in charge of all administrative functions.

Very little research using the adapted cities framework has been conducted. One possible reason for so few studies may come from the lack of an explicit process for coding cities into the framework and the difficulty in operationalizing the five categories (Carr \& Karuppusamy, 2008). Only four studies (outside of the original Frederickson et al. articles) actually use the framework to perform empirical analysis (Wood, 2002; Wood \& Fan, 2008; Carr \& Karuppusamy, 2010; Eskridge \& French, 2011). Wood (2002) finds voter turnout is dependent on form of government, with political cities having the highest voter turnout and administrative cities the lowest and direct election of mayors, separation of political powers between the mayor and council, full-time status and expanded executive authority of the mayor the likely contributors to higher voter turnout. In a study of 74 cities in 30 states Wood and Fan (2008) also find that citizens in administrative cities are more likely to rate the quality of 
services in the top rating than are those in adapted cities. Carr and Karuppusamy (2010) use the adapted cities framework to evaluate the relationship between type of city and expenditure levels; they find no linkage between structure and per capita expenditures. They also note that most adaptations had taken place in mayor-council cities with much fewer occurring within council-manager cities- $42 \%$ of council-manager cities remained as pure administrative cities (Carr \& Karuppusamy, 2009). Eskridge and French (2011), however, find in a national study of 1000 small municipalities that as municipalities more closely conform to the traditional council-manager model of local government, higher per capita expenditure levels are detected.

In this current study, it is anticipated that the allocation of working time for CAO's between the "Administrative", "Policy", and "Political" roles change as the institutional structural features of municipalities are altered between more reformed and less reformed characteristics. In past studies differences are found between mayor-council (unreformed) respondents and council-manager (reformed) respondents. Assuming changes in the institutional structures of municipalities from the traditional mayor-council and council-manager form into the 'adapted' types do affect the way cities are managed, one would expect to find changes in how the top administrative officials in these cities use their time and perceive their role within the organizational structure. Specifically, as a mayor-council community adapts the institutional characteristics of a council-manager city we would expect the mayor to alter her time accordingly. The primary feature of an "Adapted Political" city is the presence of an appointed chief administrative officer. We anticipate that this institutional change (along with the others listed above) will alter how the mayor allocates her work time. Similarly, city managers located in council-manager municipalities that adopt characteristics of unreformed cities such as those found in "Adapted Administrative" cities should exhibit similar changes in behavior. If the organization is changed to include structures such as a full time mayor that has direct input into who is hired as city manager, the manager could easily alter his time to reflect the new circumstances. We also anticipate similar differences to occur in the involvement levels of mayors and city managers. As councils and mayors in council-managers cities take on more roles found in their counterparts in mayor-council cities the city managers involvement levels should also change. We should observe similar changes in mayor-council cities as they more closely resemble council-manager cities.

Hypothesis 4: Mayors in "Adapted Political" municipalities will allocated less work time to "Management" activities and more to "Policy" and "Political" activities than mayors in "Political" cities.

Hypothesis 5: Mayors in "Adapted Political" municipalities will be less involved in the "Administrative" and "Management" role activities than mayors in "Political" cities.

\section{Nelson-Svara Typology}

In contrast to Frederickson, Johnson, and Wood's conceptualizations regarding institutional structures, Nelson and Svara (2010) argue that it is how authority is allocated that distinguishes between forms of government. They develop a seven category typology based upon a set of power allocation variables including; the legal form (council/manager or mayor/council), the presence of and who appoints the $\mathrm{CAO}$ when present, and how the mayor is selected (direct election or appointment). According to Nelson and Svara, the seven categories can be described as follows: a) Council (mayor) manager cities: these cities reflect the traditional council-manager cities with the mayor appointed by the council and the manager appointed by the council as a whole; b) Mayor-council-manager: in these council-manager communities the manager is still appointed by the council as a whole but the mayor is elected directly; c) Empowered mayor-council-manager: these council-manager communities elect a mayor directly and then allow that mayor to nominate the city manager that is then confirmed by the council as a whole; $d$ ) Mayor and council-administrator: the distinguishing feature of these mayor-council communities is the fact that the mayor and council appoint the administrator jointly; e) Mayor-council-administrator: in these mayor-council cities the mayor nominates the city administrator but the council confirms the appointment; f) Mayor-administrator-council: in these cities the mayor alone is responsible for appointing the city administrator; g) Mayor-council: these cities reflect the traditional mayor-council plan with no appointed city administrator.

Research evaluating the Nelson-Svara typology is also limited. In a 2010 study, Nelson uses the new classification system in evaluating the effect of state law on local form of government choice (Nelson, 2010). Nelson and Svara (2011) also use the new seven category system to analyze whether higher innovation rates in local governments are associated with form of government and conclude that there exists a clear distinction between forms (mayor-council versus council-manager) but not between variations within these forms. In another article Nelson and Nollenberger (2011) use the seven category typology to examine factors leading to lower conflict and cooperation in local governance processes. Their findings indicate that use of the typology explains variations in both perceived levels of conflict and cooperation associated with the decision-making process. 
Power, and its allocation among the different actors within a municipality, as described by the Nelson-Svara typology, has major implications for those jurisdiction's top officials. Changes in power allocation may alter how participants view their job and allow others to have the power to dictate formally or informally how officials allocate their time. As above, if changes in the power structures occur in municipalities that alter the traditional mayor-council and council-manager form into a 'hybrid' type structure does affect the way cities are managed, we would expect to find changes in how the top administrative officials in these cities use their time and perceive their role within the structure. Specifically, as a pure mayor-council community (with no appointed administrator) allocates the power to appoint and who is the reporting authority over the appointed administrator in a manner more characteristic of a council-manager city (appointed and reporting to the council as a whole) we would expect the mayor to use his time and perceive his role differently. The same would be true in reverse for city managers found in council-manager cities that allocate the power to appoint and the reporting authority over the appointed administrator in a manner more characteristic of an administrator in a purer mayor-council city (administrator reports directly to the mayor). This line of reasoning leads us to our next hypotheses.

Hypothesis 6: Mayors in traditional mayor-council form municipalities that are more reformed using the Nelson-Svara typology will allocated less work time to "Management" activities and more to "Policy" and "Political" activities than mayors in the less reformed "Mayor-Council" category cities.

Hypothesis 7: Mayors in traditional mayor-council form municipalities that are more reformed using the Nelson-Svara typology will be less involved in the "Administrative" and "Management" role activities than mayors in the less reformed "Mayor-Council" category cities.

Hypothesis 8: City Managers in traditional council-manager municipalities that are less-reformed using the Nelson-Svara typology will allocated less work time to "Management" and "Policy" activities and more to "Political" activities than managers in the more reformed 'Council (mayor) manager' category cities.

\section{Research Design}

This study utilizes data collected from a random national survey conducted in 2011 of municipalities in the United States drawn from a list of all 2996 mayor-council (38.3\%) or council-manager (61.7\%) municipalities having a population between 10,000 and 250,000 as listed within the International City Management Association (ICMA, 2010) Municipal Year Book 2010. The survey was delivered via mail and electronic mail to the mayor or city manager to a random sample of 800 municipalities. The sample included five hundred and two council-manager and two hundred ninety-eight mayor-council municipalities representing 49 states. Participants returned two hundred and seventy surveys (a return rate of 34\%). Four surveys were deemed unusable; three because of insufficient data completion in the survey and one municipality's population was deemed outside of the study parameters. Forty-nine surveys were discarded because they were completed by a chief administrative officer in a mayor-council city (36) or another member of staff other than the mayor or city manager (13). Of the 217 usable returned surveys, 52 came from mayors in mayor-council communities and the remaining 165 were completed by city managers working in council-manager cities (see Table 1). This is a slight underrepresentation of mayors in mayor-council cities.

Table 1. Descriptive Statistics- Population and Sample

\begin{tabular}{lllll}
\hline \multirow{2}{*}{ Municipal Type } & \multicolumn{2}{l}{ Population (1) } & \multicolumn{2}{l}{ Sample } \\
& $\mathrm{N}$ & $\%$ & $\mathrm{~N}$ & $\%$ \\
\hline Mayor-Council & 1,146 & 38 & 398 & 37 \\
Council-Manager & 1,850 & 62 & 502 & 63 \\
All Cities & 2,996 & 100 & 800 & 100 \\
\hline
\end{tabular}

The participants were asked to respond to a number of questions regarding general municipal information. Additionally, in order to classify each municipality into the proper city category for each of the classification systems, information concerning the institutional structure surrounding the mayor, city council, city staff, and the municipality in general is also solicited. To supplement the survey data, demographic data on each municipality is also obtained from the U.S. Census Bureau's website and the municipal websites of individual participants. 
To capture the time allocation information each participant is asked to allocate their individual work time among the three role activities (Note 2) describe by Wright (1969) and Newell and Ammons (1987) as discussed above (Politics, Policy, and Management). Three dependent variables representing each participant's actual allotment of $100 \%$ of work time to each of the three role activities are captured for analysis.

Participants are also asked to rate the involvement levels of both themselves and their city councils for the thirteen activities developed by Svara (2006) to measure the "Mission", "Policy", "Administrative", and "Management" dimensions of the administrator/council relationship(Note 3) using a six point Likert scale [from no involvement (0) to very high involvement (5)]. Variables are created that capture both the respondent's perceived self-involvement level and that of his council for each of the four dimensions. For use in our analysis, we sum the ratings of each dimension and then divide by the total number of activities used to rate that dimension to calculate a mean dimension rating on a scale between zero and five.

To allow us to develop three distinct models (one for each of the three typologies under consideration), the category for each municipality within each typology is identified and captured using a separate independent variable. The traditional mayor-council or council-manager typology (labeled Traditional) is identified using the actual form of government reported by each respondent municipality. The category for each municipality is also calculated and recorded in a separate variable for the five categories found within the "Adapted Cities Framework" as described by Frederickson, Johnson, and Wood (2004a) (labeled Adapted City) and the Nelson-Svara (2010) seven category classification system (labeled Nelson-Svara).

\section{Data Analysis}

Descriptive statistics for the 217 municipalities in the data set are shown in Table 2. Table 2 displays, for each typology category, the percentage of work time that the mayor or city manager allocates among the "Policy", "Politics", and "Management" activities as well as the mean involvement levels ratings for each of the four dimensions found in the Dichotomy/Duality model. Involvement ratings are included for both how each mayor and city manager rated both themselves and their respective city councils.

Table 2. Descriptive statistics - time allocations and involvement levels

\begin{tabular}{|c|c|c|c|c|c|c|c|c|c|c|c|c|c|c|}
\hline \multirow{3}{*}{ Typology } & \multirow{3}{*}{ Municipal Type } & & & \multicolumn{3}{|c|}{$\begin{array}{l}\text { Time Allocation (1) } \\
(\mathbf{1 0 0 \% )}\end{array}$} & \multicolumn{8}{|c|}{ Dichotomy/Duality Dimensions } \\
\hline & & \multicolumn{2}{|c|}{ Responses } & \multirow{2}{*}{ Politics } & \multirow{2}{*}{ Policy } & \multirow{2}{*}{ Mgmt } & \multicolumn{2}{|c|}{ MISSION } & \multicolumn{2}{|c|}{ POLICY } & \multicolumn{2}{|c|}{ ADMINISTRATION } & \multicolumn{2}{|c|}{ MANAGEMENT } \\
\hline & & $\mathbf{N}$ & $\%$ & & & & Self & $\mathrm{CC}$ & Self & $\mathrm{CC}$ & Self & CC & Self & $\mathrm{CC}$ \\
\hline \multirow{2}{*}{$\begin{array}{l}\text { Traditional } \\
\text { Typology }\end{array}$} & Mayor-Council & 52 & $24 \%$ & $22 \%$ & $33 \%$ & $44 \%$ & 4.34 & 3.66 & 4.40 & 3.52 & 4.22 & 3.09 & 4.07 & 2.31 \\
\hline & Council-Manager & 165 & $76 \%$ & $13 \%$ & $33 \%$ & $55 \%$ & 4.34 & 3.69 & 4.60 & 3.40 & 4.50 & 2.64 & 4.40 & 1.37 \\
\hline \multirow{5}{*}{$\begin{array}{c}\text { Adapted } \\
\text { Cities } \\
\text { Typology }\end{array}$} & Political & 23 & $11 \%$ & $22 \%$ & $29 \%$ & $49 \%$ & 4.29 & 3.20 & 4.37 & 3.15 & 4.24 & 2.77 & 4.24 & 1.91 \\
\hline & Adapted Political & 29 & $13 \%$ & $23 \%$ & $37 \%$ & $40 \%$ & 4.39 & 4.02 & 4.43 & 3.81 & 4.21 & 3.35 & 3.93 & 2.63 \\
\hline & Conciliated & 3 & $1 \%$ & $11 \%$ & $18 \%$ & $71 \%$ & 5.00 & 4.00 & 4.75 & 3.08 & 4.55 & 2.55 & 4.67 & 1.67 \\
\hline & $\begin{array}{c}\text { Adapted } \\
\text { Administrative } \\
\end{array}$ & 123 & $57 \%$ & $13 \%$ & $33 \%$ & $55 \%$ & 4.33 & 3.70 & 4.60 & 3.38 & 4.51 & 2.60 & 4.38 & 1.34 \\
\hline & Administrative & 39 & $18 \%$ & $12 \%$ & $34 \%$ & $54 \%$ & 4.29 & 3.66 & 4.56 & 3.51 & 4.46 & 2.77 & 4.44 & 1.59 \\
\hline \multirow{7}{*}{$\begin{array}{c}\text { Nelson } \\
\text { /Svara } \\
\text { Typology }\end{array}$} & Mayor-Council & 28 & $13 \%$ & $21 \%$ & $30 \%$ & $48 \%$ & 4.31 & 3.40 & 4.37 & 3.29 & 4.25 & 2.89 & 4.22 & 2.20 \\
\hline & $\begin{array}{c}\text { Mayor-administrator- } \\
\text { council }\end{array}$ & 8 & $4 \%$ & $18 \%$ & $35 \%$ & $47 \%$ & 4.37 & 4.21 & 4.59 & 3.88 & 4.08 & 3.46 & 3.79 & 1.62 \\
\hline & $\begin{array}{c}\text { Mayor-Council- } \\
\text { administrator }\end{array}$ & 11 & $5 \%$ & $24 \%$ & $38 \%$ & $37 \%$ & 4.36 & 3.79 & 4.39 & 3.66 & 4.27 & 3.18 & 4.00 & 2.45 \\
\hline & $\begin{array}{c}\text { Mayor \& council- } \\
\text { administrator }\end{array}$ & 5 & $2 \%$ & $34 \%$ & $35 \%$ & $31 \%$ & 4.40 & 3.93 & 4.35 & 3.95 & 4.20 & 3.47 & 3.80 & 3.73 \\
\hline & $\begin{array}{l}\text { Empowered Mayor- } \\
\text { council-administrator }\end{array}$ & 6 & $3 \%$ & $11 \%$ & $22 \%$ & $68 \%$ & 4.22 & 3.05 & 4.54 & 2.79 & 4.22 & 2.17 & 4.33 & 1.22 \\
\hline & $\begin{array}{c}\text { Mayor-council- } \\
\text { manager }\end{array}$ & 121 & $56 \%$ & $13 \%$ & $33 \%$ & $54 \%$ & 4.41 & 3.75 & 4.63 & 3.41 & 4.53 & 2.63 & 4.41 & 1.42 \\
\hline & $\begin{array}{c}\text { Council (mayor)- } \\
\text { manager }\end{array}$ & 38 & $18 \%$ & $12 \%$ & $33 \%$ & $55 \%$ & 4.11 & 3.62 & 4.48 & 3.47 & 4.45 & 2.75 & 4.38 & 1.22 \\
\hline Total/Means & All cities & 217 & $100 \%$ & $14 \%$ & $33 \%$ & $53 \%$ & 4.34 & 3.69 & 4.55 & 3.43 & 4.43 & 2.75 & 4.32 & 1.60 \\
\hline
\end{tabular}


Several general observations can be made from these descriptive statistics. Because of the number of non-mayor respondents in mayor-council municipalities, the sample obtained appears to under represent mayors in mayor-council municipalities. This may hinder our ability to generalize to the general population for mayor-council cities. Within each of the two new typologies, we find that several of the categories contain a low number of respondents. Only three municipalities fell into the "Conciliated" category using the Adapted Cities typology. Similarly, in the Nelson-Svara typology several categories have small respondents. Although these numbers are not completely out of line with the entire population of cities (Note 4), such small numbers make it difficult to generalize beyond our study concerning these specific categories.

When we examine how participants allocate their work time, two patterns appear to emerge. In general, the percentage of time allocated by respondents to the "Political" role tends to decline as we move from more unreformed categories to more reformed categories; the opposite occurs within the "Management" role. The time allocated to the "Policy" role remains fairly constant across the spectrum. Next, confirming findings made in Svara's subsequent research (Svara, 1999, 2006), in each city category of each the four dimensions outlined in the Dichotomy/Duality model, respondents rate their own involvement levels consistently higher than they rate the involvement levels of their elected city councils. For all cities regardless of typology, mayors and managers view themselves as being more involved in all four dimensions including the 'Mission' and 'Policy' roles than they perceive of their elected councils.

To begin the examination of the differences between CEOs, first the differences between mayors in mayor-council cities and city managers in council-managers cities using our typology variables are examined. Next, the effects of subdividing mayor-council cities into multiple categories using the new typologies are examined to reveal any differences among mayors between the new categories. Likewise, council-manager cities are also subdivided into multiple categories using these new typologies to reveal any differences between city managers. Finally, because half of the Dichotomy/Duality model concerns the involvement levels of the city council, the differences among how mayors and city managers perceive the involvement levels of their own city councils using the four dimensions found in the Dichotomy/Duality model (Mission, Policy, Administration, and Management) are analyzed. We examine if these new typologies reveal any insights.

To test our 8 hypotheses we employ two statistical tools. First, a difference of the mean T-tests is employed when analyzing two categories (such as the difference between means in mayor-council versus council-manager form cities or between "Political" versus "Adapted Political" cities for mayors in mayor-council cities). When more than two categories are involved ANOVA analysis is employed (such as differences between "Administrative", "Adapted Administrative", and "Conciliated" cities for city managers in council-manager cities).

\section{Analysis Results}

To investigate our first hypothesis we examine the T-tests between mayors in mayor-council cities and managers in council-manager cities for all three time allocation variables (see Figure 3 for a visual representation) and all four dimension variables in the Dichotomy/Duality model (see Table 3). The T-tests reveal that, as we hypothesized, city managers do spend significantly more time devoted to "Management" activities than do mayors $[\mathrm{t}(217)=-3.699, \mathrm{p}<0.01)]$ and mayors spend significantly more of their time on the "Politics" $[\mathrm{t}(217)=2.985, \mathrm{p}<$ $0.01)$ ] role than managers. However, we can find no evidence that mayors spend more time than managers on time allotted for the "Policy" role $[\mathrm{t}(217)=0.103, \mathrm{p}=.91)]$.
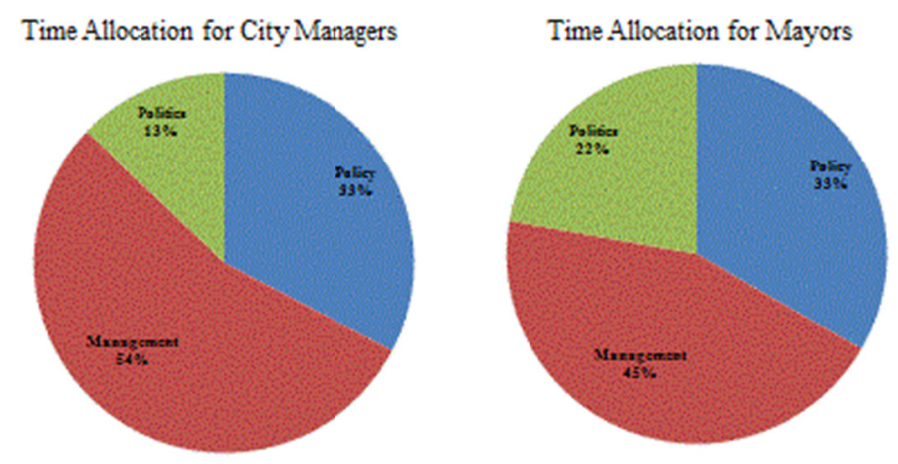

Figure 3. Time allocations for mayors and city managers 
In hypothesis 2 we proposed that mayors in mayor-council cities would be more involved in the "Mission" and "Policy" dimension activities than city managers in council-manager cities. T-tests do reveal a significant difference at the .10 level between mayors and managers in three of the four dimensions (Policy, Administration, and Management), however, all three are in the opposite direction than projected (see Table 3). Managers appear to be more involved in these three activities than mayors are. Mayors and city managers appear to spend equal levels of involvement concerning the Mission dimension activities.

Table 3. T-test self ratings - mayors versus managers

\begin{tabular}{ccc}
\hline & Variable & Traditional Typology \\
\hline \multirow{3}{*}{ Time Allocation } & Policy role & $\mathrm{t}(217)=0.103, \mathrm{p}=0.91$ \\
& Management role & $\mathrm{t}(217)=-3.699, \mathrm{p}<0.01)$ \\
& Politics role & $\mathrm{t}(217)=5.365, \mathrm{p}<0.01)$ \\
\hline \multirow{3}{*}{ Dimensions } & Mission Ratio & $\mathrm{t}(217)=-0.264, \mathrm{p}=0.79)$ \\
& Policy Ratio & $\mathrm{t}(217)=-1.876, \mathrm{p}<0.10)$ \\
& Administration Ratio & $\mathrm{t}(217)=-1.744, \mathrm{p}<0.10)$ \\
& Management Ratio & $\mathrm{t}(217)=-1.766, \mathrm{p}<0.10)$
\end{tabular}

Hypotheses 4 through 7 proposed differences between mayors in mayor-council cities when the new and more complex typologies are used to subdivide mayor-council cities into multiple categories. Table 4 displays the results of T-test and ANOVA analyses performed. In all of the analysis run for these variables only one significant difference is discovered. The amount of time that mayors allot for "Policy" activities is significantly increased $(<0.10)$ when that mayor resides in an "Adapted Political" city rather than a "Political" city, using the adapted cities typology. This finding confirms one part of hypothesis 4 but no significant differences were detected in either of the other two time allocation categories. No differences are found in the analysis to support hypotheses 5 , 6 , or 7 .

Table 4. T-tests and ANOVA of self ratings for mayors only

\begin{tabular}{cccc}
\hline & Variable & Adapted Cities Typology & Nelson/Svara Typology \\
\hline \multirow{2}{*}{ Time } & Policy & $\mathrm{t}(50)=-1.72, \mathrm{p}<0.10$ & $\mathrm{~F}(3,48)=0.62, \mathrm{p}=0.60$ \\
Allocation & Management & $\mathrm{t}(50)=1.35, \mathrm{p}=0.18$ & $\mathrm{~F}(3,48)=1.33, \mathrm{p}=0.27$ \\
& Politics & $\mathrm{t}(50)=-0.20, \mathrm{p}=0.84$ & $\mathrm{~F}(3,48)=1.05, \mathrm{p}=0.38$ \\
& Mission & $\mathrm{t}(50)=-0.50, \mathrm{p}=0.62$ & $\mathrm{~F}(3,48)=0.03, \mathrm{p}=0.99$ \\
\multirow{3}{*}{ Dimensions } & Policy & $\mathrm{t}(50)=-0.30, \mathrm{p}=0.77$ & $\mathrm{~F}(3,48)=0.21, \mathrm{p}=0.89$ \\
& Administration & $\mathrm{t}(50)=0.18, \mathrm{p}=0.86$ & $\mathrm{~F}(3,48)=0.11, \mathrm{p}=0.96$ \\
& Management & $\mathrm{t}(50)=1.20, \mathrm{p}=0.84$ & $\mathrm{~F}(3,48)=0.63, \mathrm{p}=0.60$ \\
\hline
\end{tabular}

Hypothesis 8 proposed differences between city managers when the new and more complex typologies are used to subdivide council-manager cities into multiple categories. Table 5 displays the results of ANOVA analyses performed. In all of the analysis run for these variables no significant difference is discovered between any of the categories using either new typology. No differences are found to support hypothesis 8 . 
Table 5. ANOVA for self ratings for managers only

\begin{tabular}{|c|c|c|c|}
\hline & Variable & $\begin{array}{c}\text { Adapted Cities } \\
\text { Typology }\end{array}$ & $\begin{array}{c}\text { Nelson/Svara } \\
\text { Typology }\end{array}$ \\
\hline \multirow{3}{*}{$\begin{array}{c}\text { Time } \\
\text { Allocation }\end{array}$} & Policy & $F(2,162)=1.71, p=0.18$ & $\begin{array}{c}\mathrm{F}(2,162)=1.71 \\
\mathrm{p}=0.18\end{array}$ \\
\hline & Management & $\mathrm{F}(2,162)=1.59, \mathrm{p}=0.21$ & $\begin{array}{c}\mathrm{F}(2,162)=1.59 \\
\mathrm{p}=0.21\end{array}$ \\
\hline & Politics & $F(2,162)=0.52, p=0.60$ & $\begin{array}{c}\mathrm{F}(2,162)=1.71 \\
\mathrm{p}=0.18\end{array}$ \\
\hline \multirow{4}{*}{ Dimensions } & Mission & $\mathrm{F}(2,162)=1.66, \mathrm{p}=0.19$ & $\begin{array}{c}\mathrm{F}(2,162)=3.22, \\
\mathrm{p}>0.05\end{array}$ \\
\hline & Policy & $F(2,162)=0.31, p=0.74$ & $\begin{array}{c}\mathrm{F}(2,162)=1.91 \\
\mathrm{p}=0.15\end{array}$ \\
\hline & $\begin{array}{l}\text { Administrati } \\
\text { on }\end{array}$ & $F(2,162)=0.15, p=0.86$ & $\begin{array}{c}\mathrm{F}(2,162)=1.21, \\
\mathrm{p}=.30\end{array}$ \\
\hline & Management & $F(2,162)=0.47, p=0.62$ & $\begin{array}{c}\mathrm{F}(2,162)=0.11, \\
\mathrm{p}=.90\end{array}$ \\
\hline
\end{tabular}

The Dichotomy/Duality model does, however, have a second dimension that needs to be evaluated in addition to the involvement levels of the mayors and managers in the respondent cities. Critical to the model's mix between administrator and council is the involvement level of the city councils within each of the respondent cities. In Tables 6, 7, \& 8 below the involvement level for city councils are subjected to the same analysis performed on mayors and city managers above.

Table 6. T-Test for council ratings - mayors versus managers

\begin{tabular}{llc}
\hline & Variable & Traditional Typology \\
\hline \multirow{3}{*}{ Dimensions } & Mission & $\mathrm{t}(217)=-0.240, \mathrm{p}=0.81$ \\
& Admin. & $\mathrm{t}(217)=0.870, \mathrm{p}=0.39$ \\
& Mgmt. & $\mathrm{t}(217)=3.33, \mathrm{p}>.01$ \\
& $\mathrm{t}(217)=5.59, \mathrm{p}>.01$ \\
\hline
\end{tabular}

Using a T-test, first the differences in council involvement in mayor-council and council-manager cities for all four of the model dimension are examined to test hypothesis 2 (see Table 6). We find that there is a significant difference in how mayors in mayor-council cities and city managers in council-manager cities view the involvement level of their councils for both the "Administration" and "Management" dimensions but not in the "Mission" and "Policy" dimensions. City managers in council-manager municipalities perceive that their councils are significantly less involved in the "Administration" and "Management" dimensions than do mayors in mayor-council cities. This finding is opposite of what was expected. As expected however, city managers do view their councils as being more involved in the" Mission" dimension activities than mayors, but this difference was not significant.

Table 7. ANOVA for council ratings - mayors only

\begin{tabular}{cccc}
\hline Variable & $\begin{array}{c}\text { Adapted Cities } \\
\text { Typology }\end{array}$ & Nelson/Svara Typology \\
\hline \multirow{3}{*}{ Dimensions } & Mission & $\mathrm{t}(50)=-2.89, \mathrm{p}<0.01$ & $\mathrm{~F}(3,48)=1.38, \mathrm{p}=0.26$ \\
& Policy & $\mathrm{t}(50)=-2.57, \mathrm{p}<0.05$ & $\mathrm{~F}(3,48)=1.34, \mathrm{p}=0.27$ \\
& Administration & $\mathrm{t}(50)=-2.30, \mathrm{p}<0.05$ & $\mathrm{~F}(3,48)=1.10, \mathrm{p}=0.36$ \\
& Management & $\mathrm{t}(50)=-2.08, \mathrm{p}<0.05$ & $\mathrm{~F}(3,48)=3.35, \mathrm{p}<0.05$ \\
\hline
\end{tabular}


Table 7 looks at the differences in council involvement that mayor's in mayor-council cities exhibit when mayor-council cities are subdivided into multiple categories using the new more complex typologies. T-tests reveal that in all four role dimensions, city councils in "Adapted Political" cities are seen as significantly more involved than city councils are in "Political" cities. Using the Nelson/Svara typology, only in the "Management" dimension is any significant difference discovered among mayors serving in mayor-council cities.

Table 8 displays the differences in council involvement that city managers in council-manager cities perceive when these council-manager cities are subdivided into multiple categories using the new more complex typologies. Unlike mayors in mayor-council cities, city managers appear to consider the involvement levels of councils equal across all typologies. No significant differences are observed.

Table 8. ANOVA for council ratings for managers only

\begin{tabular}{cccc}
\hline Variable & $\begin{array}{c}\text { Adapted Cities } \\
\text { Typology }\end{array}$ & Nelson/Svara Typology \\
\hline Mission & $\begin{array}{c}\mathrm{F}(2,162)=0.23, \\
\mathrm{p}=0.79\end{array}$ & $\mathrm{~F}(2,162)=2.12, \mathrm{p}=0.12$ \\
Dimensions & Policy & $\begin{array}{c}\mathrm{F}(2,162)=0.63, \\
\mathrm{p}=0.53\end{array}$ & $\mathrm{~F}(2,162)=1.95, \mathrm{p}=0.15$ \\
& Administration & $\begin{array}{c}\mathrm{F}(2,162)=0.63, \\
\mathrm{p}=0.53\end{array}$ & $\mathrm{~F}(2,162)=1.34, \mathrm{p}=0.26$ \\
& Management & $\begin{array}{c}\mathrm{F}(2,162)=0.27, \\
\mathrm{p}=0.76\end{array}$ & $\mathrm{~F}(2,162)=0.69, \mathrm{p}=0.50$ \\
\hline
\end{tabular}

\section{Discussion}

The purpose of this study is to analyze the differences between chief executive officers (mayors in mayor-council cities and city managers in council-manager cities) concerning how they allocate their work time, how involved they are in the four role dimensions described by the Dichotomy/Duality model, and how they perceive the involvement levels for their city councils using these same four role dimensions. This study seeks to enhance existing research by using two of the new more complex municipal typologies in order to subdivide the traditional mayor-council and council-manager city types into multiple categories. This allows us to observe the differences between the mayors within mayor-council form cities and the city managers within council-manager form cities. The two new typologies each use different approaches to create multiple categories for both mayor-council and council-manager cities.

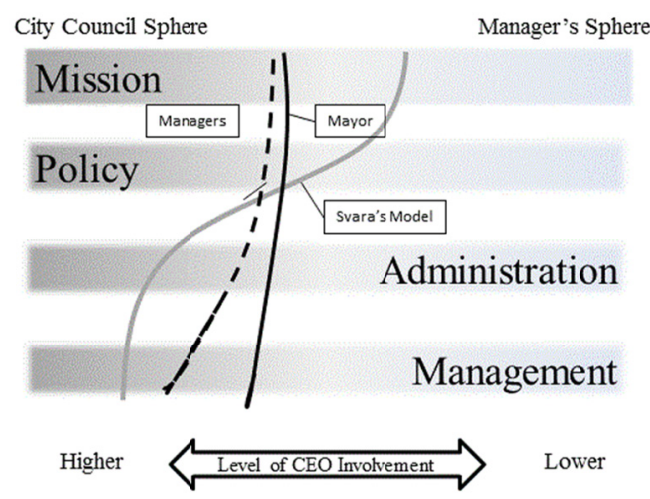

Figure 4. Reconsidered model 
Analysis shows that, concerning how CEO's allocate their work time between the "Policy", "Management", and "Politics" activities, mayors in mayor-council cities spend significantly more time on "Politics" and significantly less time on "Management" activities than do city managers in council-manager form municipalities. No difference concerning time spent on "Policy" activities between mayors and city managers is detected. Concerning the involvement levels of CEO's using the four role dimensions of "Mission", "Policy", "Administration", and "Management", analysis finds no difference between mayors and city managers when it comes to "Mission" activities but (at least at the .10 significance level) there is a difference between mayors and city managers in the "Policy", "Administration", and "Management" dimensions; city managers are significantly more involved in these three activities than are mayors (Figure 4 superimposes these new involvement levels for mayors and city managers upon the original Dichotomy/Duality model). This finding tends to confirm prior research that shows that city managers participate in many activities that go beyond just the pure administrative role envisioned in the classical politics/administration dichotomy. However, when the new typologies are utilized to observe differences for just mayors within mayor-council cities and just city managers within council-manager cities (Tables $\mathbf{4} \boldsymbol{\&} \mathbf{5}$ ) for these same variables only one significant difference can be found (mayors in "Adapted Political" cities allocates more time to "Policy" activities than mayors in "Political" cities). Since the major difference between the "Political" and "Adapted Political" city categories is the presence of an appointed chief administrative officer (CAO), one may conclude that there is a correlation between the presence of a fulltime CAO and the amount of time that a mayor allocates to "Policy" activities. Perhaps the CAO takes some of the burden for "Policy" activities off of the mayor in these cities and thus reduces the amount of time the mayor needs to spend on such activity. With this one exception, all of the mayors within mayor-council cities and all of the city managers within council-manager cities appear to allocate their time and become involved in these four dimensions equally.

One of the most interesting findings discovered in the analysis appears when how these same mayors and city managers perceive the involvement level of their city councils in the "Mission", "Policy", "Administrative", and "Management" role dimensions is examined. Analysis reveals that mayors and city managers perceive their council involvement levels differently for both the "Administrative" and "Management" dimension activities. Perhaps this should not be a surprise when the fact is considered that the activities incorporated within these two dimensions (for example program implementation) constitute much of the training that managers obtain in a typical public administration education (62\% of city managers indicated public administration as their field of education). What may be harder to explain is the finding that mayors in "Adapted Political" cities perceive consistently higher involvement levels for their city councils in all four dimensions that do mayors in "Political" cities. However, we do not observe this same pattern when we use the Nelson-Svara typology to subdivide mayor-council communities. This again, may be an effect upon council of having a fulltime appointed CAO or at least a perception by the mayor that having the CAO increases the involvement level of the council in these activities. We do not find any differences among city managers perceptions of council involvement levels when council-manager cities are subdivided and categorized using the new typologies (Table 8). It appears that having a fulltime city manager or administrative officer correlates with an increase in the involvement level of city councils in the activities associated with these four dimensions regardless of city form.

\section{Conclusion}

Chief executive officers perception of their roles and time allocation between activities can supply us information about the priorities these executives privilege. How involved in these activities that they perceive their city councils to be can help us to understand the relationship that these mayors and city managers have with those councils. When observing the differences between mayors and managers we discover that several significant differences do exist in how these CEOs allocate their time, their involvement levels in the four dimensions, and how they perceive their councils involvement levels in these same activities. However, the blending of the structural features of municipalities in the United States has been well documented by scholars in recent years (Adrian, 1988; Moulder, 2008; MacManus \& Bullock, 2003; Ebdon \& Brucato, 2000; Frederickson, Logan, and Wood, 2003). These various authors suggest that the traditional dichotomous classification system most scholars commonly use to describe the majority of municipalities as either mayor/council or council/manager may not prove adequate today when analyzing the differences found between these communities (DeSantis \& Renner, 2002). By using two of the new and most comprehensive typology systems for categorizing local governments in the United States in this study, the analysis is able to look beyond just the difference between mayor and city managers and examine differences among the mayors within mayor-council cities and the city managers within council-manager cities. Using the multiple categories in these new typologies enables us to detect subtle differences concerning how chief executive officers in these municipalities utilize their work time and perceive their city council as well as their own roles. Detecting such differences adds one small brick onto the theoretical 
foundations attached to using these new typologies for research and helps us better understand these chief executive officers.

\section{References}

Adrian, C. R. (1988). Forms of City Government in American History. In Municipal Year Book (pp. 3-11). Washington D.C: International City/County Management Association.

Aleshire, F. (1977). The American City Manager: New Style, New Game. National Civic Review, 66(5), 235-236. http://dx.doi.org/10.1002/ncr.4100660506

Ammons, D. N., \& Newell, C. (1988). City Managers Don't Make Policy: A Lie, Let's Face It. Public Management, 70(12), 14-17.

Blubaugh, D. A. (1987). The Changing Role of the Public Administrator. Public Management, 69(6), 7-10.

Bosworth, K. L. (1958). The Manager is a Politician. Public Administration Review, 18, 216-222. http://dx.doi.org/10.2307/973434

Browne, W. P. (1985). Municipal Managers and Policy: A Partial Test of the Svara Dichotomy-Duality Model. Public Administration Review, 45(5), 117-123. http://dx.doi.org/10.2307/3109939

Carr, J. B., \& Karuppusamy, S. (2008). The Adapted Cities Framework: On Enhancing its Use in Empirical Research. Urban Affairs Review, 43(6), 875-886. http://dx.doi.org/10.1177/1078087407311396

Carr, J. B., \& Karuppusamy, S. (2009). Beyond Ideal Types of Municipal Structure. The American Review of Public Administration, 39(3), 304-321. http://dx.doi.org/10.1177/0275074008319217

Carr, J. B., \& Karuppusamy, S. (2010). Reassessing the Link between City Structure and Fiscal Policy: Is the Problem Poor Measures of Governmental Structure? The American Review of Public Administration, 40(2), 209-228. http://dx.doi.org/10.1177/0275074009334641

Demir, T. (2009). The Complementarity View: Exploring a Continuum in Political-Administrative Relations. Public Administration Review, 69(5), 876-888. http://dx.doi.org/10.1111/j.1540-6210.2009.02037.x

DeSantis, V. S., \& Newell, C. (1996). Local Government Manager's Career Paths. International City Management Association Municipal Year Book, 63.

DeSantis, V. S., \& Renner, T. (2002). City Government Structures: An Attempt at Clarification. State and Local Government Review, 54(3), 95-104. http://dx.doi.org/10.1177/0160323X0203400202

Dunn, D. D., \& Legg Jr, J. S. (2002). Politics and Administration in U.S. Local Governments. Journal of Public Administration Research \& Theory, 12(3), 401. http://dx.doi.org/10.1093/oxfordjournals.jpart.a003540

Ebdon, C., \& Brucato, P. F., Jr. (2000). Government Structure in Large U.S. Cities: Are Forms Converging? International Journal of Public Administration, 23(12), 2209-2235. http://dx.doi.org/10.1080/0190069 0008525544

Eskridge, R. D., \& French, P. E. (2011). Using the Adapted Cities Framework to Evaluate Per Capita Expenditures in Small U.S. Cities. Public Budgeting, Accounting, and Financial Management, 23(3), 338-360.

Farnham, P. G. (1986). The Impact of Government Function Responsibility on Local Expenditure. Urban Affairs Quarterly, 22(1), 151-165. http://dx.doi.org/10.1177/004208168602200108

Frederickson, H. G., \& Johnson, G. A. (2001). The Adapted American City: A Study of Institutional Dynamics. Urban Affairs Review, 36(6), 872-884. http://dx.doi.org/10.1177/10780870122185127

Frederickson, H. G., Johnson, G. A., \& Wood, C. (2004a). The Adapted City: Institutional Dynamics and Structural Change. Armonk, NY: M.E. Sharpe.

Frederickson, H. G., Johnson, G. A., \& Wood, C. (2004b). The Changing Structure of American Cities: A Study of the Diffusion of Innovation. Public Administration Review, 64(3), 320-330. http://dx.doi.org/10.1111/j.1540-6210.2004.00376.x

Frederickson, H. G., Logan, B., \& Wood, C. (2003). Municipal Reform in Mayor-Council Cities: A Well-Kept Secret. State and Local Government Review, 35(1), 7-14. http://dx.doi.org/10.1177/0160323X0303500101

Frederickson, H. G., Wood, C., \& Logan, B. (2001). How American City Governments Have Changed: the Evolution of the Model City Charter. National Civic Review, 90(1), 3-18. http://dx.doi.org/10.1002/ncr.90101

French, P. E., \& Folz, D. H. (2004). Executive Behavior and Decision Making in Small U.S. Cities. The American Review of Public Administration, 34(1), 52-66. http://dx.doi.org/10.1177/0275074003259186 
Giles, W. A., Gabris, G. T., \& Krane, D. A. (1980). Dynamics in Rural Policy Development: The Uniqueness of County Government. Public Administration Review, 40(1), 24-28. http://dx.doi.org/10.2307/976104

Golembiewski, R. T., \& Gabris, G. T. (1994). Today's City Managers: A Legacy of Success - Becoming - Failure. Public Administration Review, 54(6), 525-536. http://dx.doi.org/10.2307/976671

Hale, M. L. (1989). The Nature of City Manager's Work. In H. G. Frederickson (Ed.), Ideal \& Practice in Council-Manager Government. Washington, D.C.: ICMA

Hansell, B. (1998a). Is It Time to 'Reform' The Reform? (Part I). Public Management, 80(12), 15-16.

Hansell, B. (1998b). Is It Time to 'Reform' The Reform? (Part II). Public Management, 81(1), 28.

Kessel, J. H. (1962). Governmental Structure and Political Environment: A Statistical Note About American Cities. American Political Science Review, 56(September), 615-620. http://dx.doi.org/10.2307/1952494

Killiam, J., \& Chaudhury, E. (2010). Continuity and Change in the Role of City Managers. Municipal Year Book (pp. 10-18). Washington D.C.: International City/County Management Association.

Loveridge, R. O. (1968). The City Manager in Legislative Politics. Polity, 1(2), 213-236. http://dx.doi.org/10.2307/3233954

Lynn, L. (2001). The Myth of the Bureaucratic Paradigm. Public Administration Review, 61(2), 144-160. http://dx.doi.org/10.1111/0033-3352.00016

MacManus, S. A., \& Bullock, C. S., III. (2003). The form, structure, and composition of America's municipalities in the new millennium. Municipal Year Book (pp. 3-18). Washington D.C.: International City/County Management Association.

Montjoy, R. S., \& Watson, D. J. (1995). A Case for Reinterpreted Dichotomy of Politics and Administration as a Professional Standard in Council-Manager Government. Public Administration Review, 55(3), 231-239. http://dx.doi.org/10.2307/3110241

Moulder, E. R. (2008). Municipal form of Government: Trends in Structure, Responsibility, and Composition. Municipal Year Book (pp. 27-33). Washington D.C.: International City/County Management Association.

Nelson, K. L. (2010). State-Level Autonomy and Municipal Government Structure: Influence on Form of Government Outcomes. The American Review of Public Administration, 41(5), 542-561. http://dx.doi.org/10.1177/0275074010382134

Nelson, K. L., \& Svara, J. H. (2010). Adaptation of Models Versus Variations in Form: Classifying Structures of City Government. Urban Affairs Review, 45(4), 544-562. http://dx.doi.org/10.1177/1078087409356349

Nelson, K. L., \& Nollenberger, K. (2011). Conflic and Cooperation in Municipalities: Do Variations in Form of Government Have an Effect?. Urban Affairs Review, 47(5), 696-720. http://dx.doi.org/10.1177/1078087411409129

Newell, C., \& Ammons, D. N. (1987). Role Emphases of City Managers and Other Municipal Executives. Public Administration Review, 47(3), 246-253. http://dx.doi.org/10.2307/975903

Newell, C., Glass, J. J., \& Ammons, D. N. (1995). City Managers Roles in a Changing Political Environment. In H. G. Frederickson (Ed.), Ideal \& Practice in Council-Manager Government (2nd ed.). Washington, D.C.: ICMA.

Nolting, O. F. (1969). Progress and Impact of the Council-Manager Plan. Chicago: Public Administration Service.

Protasel, G. (1995). Leadership in Council-Manager Cities - The Institutional Implications. In H. G. Frederickson (Ed.), Ideal \& Practice in Council-Manager Government (2nd ed.). Washington, D.C.: ICMA.

Rosenbloom, D. (2008). The Politics-Administration Dichotomy in U.S. Historical Context. Public Administration Review, 68(1), 57-60. http://dx.doi.org/10.1111/j.1540-6210.2007.00836.x

Sanders, H. T. (1979). Governmental Structure in American Cities. International City Management Association Municipal Year Book, 46.

Sherbenau, E. (1961). Class, Participation, and the Council-Manager Plan. Public Administration Review, 131-135. http://dx.doi.org/10.2307/973951

Stillman, R. J. (1974). The Rise of the City Manager. Albequerque: University of New Mexico Press. 
Svara, J. H. (1985). Dichotomy and Duality: Reconceptualizing the Relationship between Policy and Administration in Council-Manager Cities. Public Administration Review, 45(1), 221-232. http://dx.doi.org/10.2307/3110151

Svara, J. H. (1988a). The Complementary Roles of Officials in Council-Manager Government. International City Management Association Municipal Yearbook, 23-33.

Svara, J. H. (1988b). Conflict, Cooperation, and Separation of Powers in City Government. Journal of Urban Affairs, 10(4), 357-372. http://dx.doi.org/10.1111/j.1467-9906.1988.tb00167.x

Svara, J. H. (1995). Policy and Administration: City managers as comprehensive professional leaders. In H. G. Frederickson (Ed.), Ideal \& Practice in Council-Manager Government (2nd ed.). Washington, D.C.: ICMA.

Svara, J. H. (1999a). Complementarity of Politics and Administration as a Legitimate Alternative to the Dichotomy Model. Administration and Society, 30(6), 676-705. http://dx.doi.org/10.1177/00953 999922019049

Svara, J. H. (1999b). The Shifting Boundary between Elected Officials and City Managers in Large Council-Manager Cities. Public Administration Review, 59(1), 44-53. http://dx.doi.org/10.2307/977478

Svara, J. H. (2006). The Search for Meaning in Political-Administrative Relations in Local Government. International Journal of Public Administration, 29, 1065-1090. http://dx.doi.org/10.1080/019006906008 54704

Waldo, D. (1948). The Administrative State. New York: Ronald Press Co.

Wikstrom, N. (1979). The Mayor as a Policy Leader in the Council-Manager from of Government: A View From The Field. Public Administration Review, May/June, 270-276. http://dx.doi.org/10.2307/975952

Wood, C. (2002). Voter Turnout in City Elections. Urban Affairs Review, 38(2), 209-231. http://dx.doi.org/10.1177/107808702237659

Wood, C., \& Fan, Y. (2008). The Performance of The Adapted City From the Perspective of Citizens. Public Performance \& Management Review, 31(3), 407-430. http://dx.doi.org/10.2753/PMR1530-9576310305

Wright, D. S. (1969). The City Manager as a Development Administrator. In R. T. Daland (Ed.), Comparative Urban Research. Beverly Hills, CA: Sage Publications.

\section{Notes}

Note 1. Hansell suggested a "classic" form (mayor is elected among the council); a "mayor (at-large)-council-manager" type (mayor is directly elected but with power similar to all other council members); a "mayor (empowered) council-manager" (separately elected mayor with special powers such as the veto, budget review, etc.); and lastly a "mayor (separation of powers) - council-manager" type (mayor is chief executive, nominates the manager who serves as chief operating officer.).

Note 2. Participants were asked to allocate $100 \%$ of their time between the three broad activity areas: a) policy (all meeting with council members, agenda setting, and policy development, proposal, and advise), b) management (staffing, budgeting, coordination of departments, evaluating, directing, etc.), and c) political activities (Includes ceremonies, public relations, meetings with other governmental officials at other levels of government, speeches, etc).

Note 3. Survey participants were asked to rate the perceived involvement level of themselves and their city council for thirteen specific related activities, three for mission activities, four for policy activities, three for administrative activities, and three for management activities using Svara's recommendations and a six point Likert scale. The three mission related activities included: a) determining the purpose and services of municipal government, b) developing strategies of future development of the municipality, and c) setting long-term fiscal priorities for the municipality. The four policy related activities included: a) developing annual goals and objectives for municipal programs, b) the budget process, c) identifying current issues that require attention by the municipal government, and e) developing solutions to current issues. The three specific administrative related activities included: a) evaluating the accomplishment of specific programs, b) resolving citizen's complaints about services, and c) implementing programs and delivering services. The three specific management related activities include: a) changing management practices or reorganizing city government, b) hiring decisions about department heads, and hiring decision: employees below department head level. 
Note 4. Based upon their research, Nelson and Nollenberger (2011) list the number of municipalities within each of the 7 categories for all cities over 10,000 populations as follows:

- Council-manager

- Mayor-Council-Manager

- Empowered Mayor-council-manager

- Mayor and Council- administrator

- Mayor-council-administrator

- Mayor-administrator-council

- Mayor-council
$21.0 \%$

$35.0 \%$

$.8 \%$

$7.3 \%$

$9.0 \%$

$5.0 \%$

$21.0 \%$

\section{Copyrights}

Copyright for this article is retained by the author(s), with first publication rights granted to the journal.

This is an open-access article distributed under the terms and conditions of the Creative Commons Attribution license (http://creativecommons.org/licenses/by/3.0/). 